\title{
Links between Floods and Other Water Issues in the Himalayan and Tibetan Plateau Region
}

\author{
Robert J. Wasson and Barry Newell*
}

\begin{abstract}
The Himalayan and Tibetan region and adjacent plains are highly floodprone, causing massive damage in both urban and rural areas. While this is well known and moderately well studied, we contend that floods are connected to other water issues in this region and hence should not be analyzed in isolation. We use influence diagrams to present initial hypotheses concerning possible cause-effect links between key variables of the wider system. The links emphasize a need to take a much broader than usual view to minimize the unintended consequences of governance interventions, and to avoid worsening already highly dangerous situations. The governance challenges revealed by such a view are immense, but the large-scale framework presented here indicates a need for a collaborative, cross-sectoral approach to adaptive governance. While some of what is suggested in this paper is geopolitically unrealizable at the moment, the discussion is offered as a guide to future planning.
\end{abstract}

KEYWORDS: floods, governance, Tibet, Himalaya, urban and rural, compound disasters, system dynamics

DOI: http:/ /dx.doi.org/10.5509/2015883653

\section{Introduction: Scope, Definitions, and Methods}

Tloods in the Himalayan and Tibetan plateau region cause frequent disasters in the mountains and on the plains, affecting urban areas and their hinterlands alike. ${ }^{1}$ In general, governance regimes treat floods

RoBERT J. WASSON is a senior research fellow at the Institute of Water Policy, Lee Kuan Yew School of Public Policy, National University of Singapore. Email: spprjw@nus.edu.sg; wasson.robertj@gmail.com.

BARRY NewELL is a physicist with a focus on the dynamics of human-environment systems. He is affiliated with the Australian National University and the United Nations University. He is co-author of Understanding Human Ecology: A systems approach to sustainability (Routledge, 2015). Email: barry. newell@anu.edu.au.

* Mike Douglass and Michelle Miller are thanked for inviting this paper and providing comments on earlier drafts. We thank the two reviewers and the editor for helping to make this paper more succinct and comprehensive.

1 Mike Douglass, "The Urban Transition of Environmental Disaster Governance in Asia” (Asia Research Institute, National University of Singapore, 2013). 
separately from other water issues in the region. We contend that this is an inadequate approach because many of these phenomena are linked or are likely to be linked, including: pollution and overuse of groundwater; pollution and overuse of surface water; reservoir sedimentation and loss of water storage; levees (embankments) on rivers designed to control floods cause waterlogging of cropland, health impoverishment, and complacency that exacerbates exposure to embankment-breaching floods; decreased groundwater recharge as a result of the confinement of floods between embankments; a gain, followed by a substantial loss, in river flow (and therefore in water resources) as a result of glacier loss in the mountains; and the cumulative impacts on the economy and poverty alleviation.

Given the likely connections between these phenomena, this paper has three purposes. First, we synthesize key elements of the flood regimes in the region, including past and possible future trends, the causes of floods, and trends in human vulnerability to floods. Second, we document and postulate linkages between floods and other serious water issues, as a novel contribution to governance in the region. Third, we consider the key governance challenges raised by the approach taken in this paper. Much of the information comes from South Asia, reflecting the experience of the authors.

It has become commonplace for environmental disasters to be seen as the product of threats and vulnerability. The latter is defined by Wisner et al. as: "the characteristics of a person or group and their situation that influence their capacity to anticipate, cope with, resist and recover from the impact of a natural hazard"; and by the IPCC as "the propensity or predisposition to be adversely affected. Vulnerability encompasses a variety of concepts and elements including sensitivity or susceptibility to harm and lack of capacity to cope and adapt." 2 Threats are usually viewed as natural, as in the first definition of vulnerability, while vulnerability is a result of human decisions and actions. Rousseau, following the Lisbon earthquake in the eighteenth century, was an early advocate of this distinction. ${ }^{3}$ Like many others we use the term "risk" to refer to the combination of threat and vulnerability which, when activated, becomes a disaster.

Scientists are less supportive of the idea that flood threats are natural, in the face of evidence for anthropogenic climate change and human-induced intensification of precipitation (and possibly floods). ${ }^{4}$ Threats caused by

2 Phil O'Keefe, Ken Westgate, and Ben Wisner, "Taking the Naturalness Out of Natural Disasters," Nature 260 (1976): 566-567; Ben Wisner et al., eds., At Risk: Natural Hazards, People's Vulnerability and Disasters (London: Routledge, 2004), 471; IPCC, "Summary for policymakers," in Climate Change 2014: Impacts, Adaptation, and Vulnerability. Part A: Global and Sectoral Aspects. Contribution of Working Group II to the Fifth Assessment Report of the Intergovernmental Panel on Climate Change, eds. C.B. Field et al. (Cambridge and New York: Cambridge University Press, 2014), 1-32.

3 Marie-Hélène Huet, The Culture of Disaster (Chicago: University of Chicago Press, 2012).

4 Kevin E. Trenberth, "Framing the Way to Relate Climate Extremes to Climate Change," Climatic Change 115, no. 2 (2012): 283-290. 
pollution and overuse of water are entirely human, and are technological in origin. ${ }^{5}$ While it is not possible to attribute any particular flood to anthropogenic climate change, Trenberth argues that all hydro-climatic extremes are to some extent human-induced or soon will be. Therefore they are technological threats just like pollution. ${ }^{6}$

In this paper earthquakes are considered to be natural events, with a few exceptions. ${ }^{7}$ In summary we use the term "threat" to refer to events having both natural and technological causes, and the term "vulnerability" to reflect characteristics of human situations. A disaster occurs when a threat (or threats) is (are) activated and vulnerability is high.

Many floods, with linkages to other water threats, trigger compound disasters. That is, they set off a series of cascading events affecting both the ecosystem and human society, and in aggregate overwhelm the community's ability to respond, particularly where vulnerability is high and response resources are limited. ${ }^{8}$ Such disasters may also be cumulative, arising from multiple threats. ${ }^{9}$

To document and analyze linkages between floods and other water issues, we have used graphical techniques that have their origin in system dynamics. ${ }^{10}$ Figures 2 through 5 are cause-effect diagrams that show the major connections between phenomena but not the strength of the connections; that topic requires further analysis. Cause-effect diagrams offer an overview and an important first step to the unraveling of the complexity of social-ecological systems.

Some of the relationships depicted in the cause-effect diagrams are either poorly understood, or are speculative and need to be tested. Likewise feedback effects, and other changes to the magnitude of variables, need to be quantified wherever possible. The approach offered here is an essential initial step towards a systems approach to complex questions such as: What

For different perspectives, see Ulrich Beck, Risk Society: Towards a New Modernity (London: Sage, 1992); Merryn Ekberg, "The Parameters of the Risk Society," Current Sociology 55, no. 3 (2007): 343-366; Hilary Rose, "Risk, Trust and Skepticism in the Age of the New Genetics," in The Risk Society and Beyond: Critical Issues for Social Theory, eds. Barbara Adam, Ulrich Beck and Joost van Loon (London: Sage, 2000).

6 Thomas C. Peterson et al., "Explaining Extreme Events of 2012 from a Climate Perspective," American Meteorological Society 94, no. 9 (2013): S1-S74.

7 For a few exceptions, see Bill McGuire, "Climate Forcing of Geological and Geomorphological Hazards," Philosophical Transactions of the Royal Society A: Mathematical, Physical and Engineering Sciences 368, no. 1919 (2010): 2311-2315.

$8 \quad \mathrm{ADB}$ and ADB Institute, Disaster Risk Management in Asia and the Pacific: Issues Paper no. 75 (Tokyo: Asian Development Bank Institute, 2013).

9 Timo Assmuth, Mikael Hildén and Christina Benighaus, "Integrated Risk Assessment and Risk Governance as Socio-political Phenomena: A Synthetic View of the Challenges," Science of the Total Environment 408, no. 18 (2009): 3943-3953.

10 John D. Sterman, Business Dynamics: Systems Thinking and Modeling for a Complex World (Irwin: McGraw Hill, 2000); Donella H. Meadows, Thinking in Systems (Vermont: Chelsea Green Publishing, 2008). 
is likely to happen to rural and urban livelihoods and health if floods worsen, current water sources remain polluted, and dry season flows diminish? To this analysis could be added other driving factors such as population, economic growth or decline, production and trade patterns, consumption patterns, and technological developments. The complexity of such an approach may defeat the construction of workable models but at least would enable the examination of scenarios like those used in water footprint studies. ${ }^{11}$

\section{The Physical, Hydrologic, and Vulnerability Setting}

Nine large rivers rise on the Tibetan Plateau and the Himalaya: the Syr Darya, Amu Darya, Indus, Ganga, Brahmaputra, Irrawaddy/Salween, Mekong, Yellow (Huang He), and the Yangtze (figure 1) in Afghanistan, Tajikistan, Uzbekistan, Kyrgyzstan, Turkmenistan, China, India, Bhutan, Nepal, Pakistan, Laos, Thailand, Cambodia, Vietnam, Myanmar, and Bangladesh. We emphasize the Indus, Ganga, Brahmaputra, and Yangtze catchments, and therefore Pakistan, India, and China.

Water for human consumption in this region comes from rainfall, groundwater and glacier and snowmelt. According to Immerzeel and Bierkens, melting of glaciers produces 26 percent of annual river flows in the Indus; Bolch et al. estimate this figure at 50 percent. ${ }^{12}$ In the Ganga and Brahmaputra catchments, melting of glaciers produces about 9 percent and 12 percent, respectively, of annual river flows according to Bolch et al. In the Ganga catchment Immerzeel and Bierkens estimate the proportion at 3 percent. These differences, apart from data uncertainties, arise from a higher proportion of glacier meltwater where glacier volumes are large and monsoon rainfall is small, as in the Karakoram/Hindu Kush region. In the Brahmaputra catchment glacier mass is similar to that of the Indus but monsoon rainfall is higher.

The human population dependent upon these water resources is vulnerable to multiple threats. Immerzeel and Bierkens assessed the risks using the following variables: dependence on glacier meltwater, groundwater depletion, reservoir potential, future precipitation and its uncertainty, the level of economic development, and population growth. They conclude that water availability is most at risk in the Amu Darya catchment because of high dependence on meltwater, a small projected increase in precipitation, and limited potential for reservoir construction. However, the number of people

11 Ertug A. Ercin and Arjen Y. Hoekstra, "Water Footprint Scenarios for 2050: A Global Analysis," Environment International 64 (2014): 71-82.

12 W. W. Immerzeel and M.F.P. Bierkens, "Asia's Water Balance," Nature Geoscience 5, no. 12 (2012): 841-842; T. Bolch et al., "The State and Fate of Himalayan Glaciers," Science 336, no. 6079 (2013): $310-314$. 


\section{Figure 1}

Catchments for Asian Rivers Rising on the Tibetan Plateau and the Himalaya-Karakoram-Hindu Kush

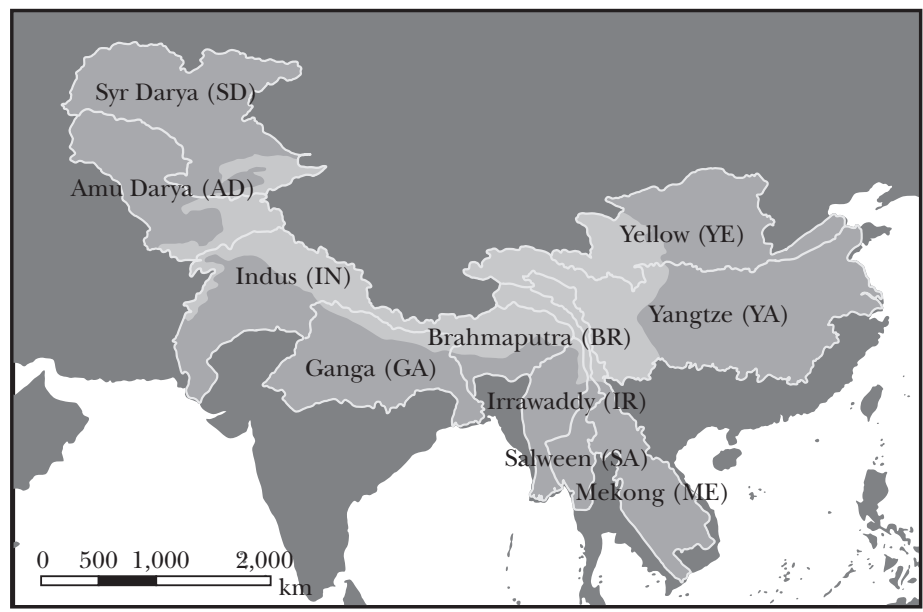

Source: Redrawn from a map published in W.W. Immerzeel and M.F.P. Bierkens, “Asia's Water Balance,” Nature Geoscience 5, no. 12 (2012): 841.

affected is relatively small. Communities in the Indus catchment are also at high risk because of their increasing dependence on meltwater and groundwater. This increase is driven by rapid population growth and economic development in an area that is already densely populated. The Syr Darya catchment is at intermediate risk, mainly because of low population. The Ganga catchment is also at intermediate risk because of a projected increase in precipitation, high potential for reservoir construction, and low dependence on meltwater. The Brahmaputra, Irrawaddy, Salween, Mekong, Yellow, and Yangtze catchments are all at low risk. Some of these results are surprising and would be clearer if threats and vulnerability had been separated.

\section{Cause-Effect Structures}

\section{Glacier Mass and Non-Monsoon Flows in the Mountains}

Chronic dry-season water shortages are likely to occur in the mountains as glaciers retreat. Most glaciers in the Himalaya-Karakoram ranges (HK) have retreated since the mid-nineteenth century, but some glaciers in the Karakoram have been stable or have expanded. ${ }^{13}$

13 T. Bolch et al., "The State," 310-314. 
The paramount role of temperature and precipitation in glacier-mass dynamics, and their impact on river flows and groundwater, are included in the cause-effect diagram (figure 2). As glacier mass reduces meltwater flows increase, and as glacier mass increases meltwater flows decrease. There is little or no trend in Himalayan precipitation, but winter precipitation in the Karakoram has increased. Warming has increased in both areas, although others claim that the temperature has decreased. ${ }^{14}$ Increased temperature in the humid monsoon-dominated parts of the Himalaya has resulted in glacier mass loss. In the stable and advancing glaciers of the northwest, increased winter precipitation and possibly reduced summer temperatures have produced glacial growth. The increased precipitation in winter in the Upper Indus River is reflected in a reconstruction of river flows using tree rings. ${ }^{15}$ Glaciers in the upper Yangtze River have been declining for decades as spring temperatures have risen. ${ }^{16}$

Figure 2

Glacier Mass and Non-Monsoon River Flows

in the Mountains ${ }^{17}$

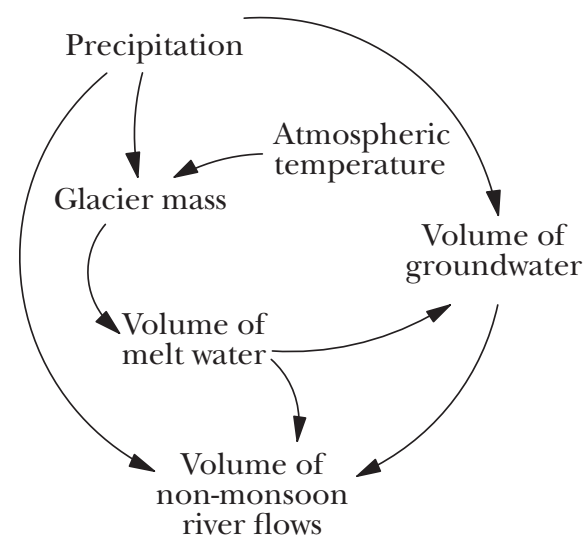

Source: Authors

14 H.J. Fowler and D.R. Archer, "Conflicting Signals of Climatic Change in the Upper Indus Basin," Journal of Climate 19, no. 17 (2006): 4276-4293; M.S. Shekhar et al., "Climate-change Studies in the Western Himalaya," Annals of Glaciology 51, no. 54 (2010): 105-112.

15 Edward R. Cook et al., "Five Centuries of Upper Indus River Flow from Tree Rings," Journal of Hydrology 486 (2013): 365-375.

16 Yong P. Shen et al., "Impacts of Climate Change on Glacial Water Resources and Hydrological Cycles in the Yangtze River Source Region, the Qinghai-Tibetan Plateau, China: A Progress Report," Sciences in Cold and Arid Regions 1, no. 6 (2009): 475-495.

17 In this cause-effect diagram the blocks of text represent system state variables (stocks) and the arrows represent state-change processes (flows). 
Rees and Collins ${ }^{18}$ have shown by modelling that in the western Himalayan region, glacial meltwater will peak in 2060 at about 150 percent of initial flows. In the east, meltwater will peak at about 170 percent of initial flows in 2070 to 2080 . When the glaciers are gone-in the mid-twenty-first centuryannual mean flows are likely to be about 33 percent and 4 percent to 18 percent less than in the 1990s in the west and east, respectively. Flows will then become dependent almost entirely upon precipitation.

Immerzeel et al. ${ }^{19}$ use climate projections to show that the response of glaciers is similar in the catchments of the Indus and Ganga Rivers, where glaciers will recede and meltwater run-off will peak around 2050 and then decline, remaining above current levels until approximately 2100 . The fact that these results differ substantially from previous studies, including the study by Rees and Collins, provides both optimism (because the latter analysis is more complete) and caution (in the use of projections).

Meltwater in the upper Yangtze is expected to increase by about 29 percent by 2050 (over its 1970 value, which was only 0.13 percent of the river's mean annual run-off) as temperature is expected to rise by $2^{\circ} \mathrm{C}$ and precipitation by about $29 \mathrm{~mm}$ annually. ${ }^{20}$ It is estimated that the area of monsoonal glaciers in China will be reduced by about 75 to 80 percent by $2100 .{ }^{21}$ Sediment cover on glaciers complicates the relationship between changes of climate and glaciers. ${ }^{22}$ Glacial retreat rates in the Himalaya are high in sediment-free glaciers and zero where sediment cover is greater than 20 percent.

Groundwater in the Himalaya can be a significant component of the water budget. ${ }^{23}$ In Nepal, groundwater (from precipitation and meltwater) delivers about twice as much water to rivers as snow and glacier melt, amounting to about 20 percent of annual river flows. As precipitation and meltwater increase so will groundwater (figure 2). While the linkages are clear, projections of changes are far from clear because of poor spatial coverage of data and uncertain model results.

\section{Floods in the Mountains}

A second cause-effect diagram (figure 3) is focused on floods, an acute threat in the mountains of Pakistan, India, Nepal, and China. This diagram also

18 Gwyn Rees and David N. Collins, "Regional Differences in Response of Flow in Glacier-fed Himalayan Rivers to Climatic Warming," Hydrological Processes 20, no. 10 (2006): 2157-2169.

19 W.W. Immerzeel, F. Pellicciotti, and M.F.P. Bierkens, "Rising River Flows throughout the Twentyfirst Century in Two Himalayan Glazierized Watersheds," Nature Geoscience 6, no. 9 (2013): 742-745.

20 Weichai Wang et al., "A First-order Method to Identify Potentially Dangerous Glacial Lakes in a Region of the Southeastern Tibetan Plateau," Mountain Research and Development 31 (2011): 122-130.

21 Yafeng Shi and Shiyin Liu, "Estimation on the Response of Glaciers in China to the Global Warming in the 21st Century," Chinese Science Bulletin 45, no. 7 (2000): 668-672.

22 Dirk Scherler, Bodo Bookhagen, and Manfred R. Strecker, "Spatially Variable Response of Himalayan Glaciers to Climate Change Affected by Debris Cover,” Nature Geoscience 4, no. 3 (2011): $156-159$.

23 Christoff Andermann et al., "Impact of Transient Groundwater Storage on the Discharge of Himalayan Rivers,” Nature Geoscience 5, no. 2 (2012): 127-132. 


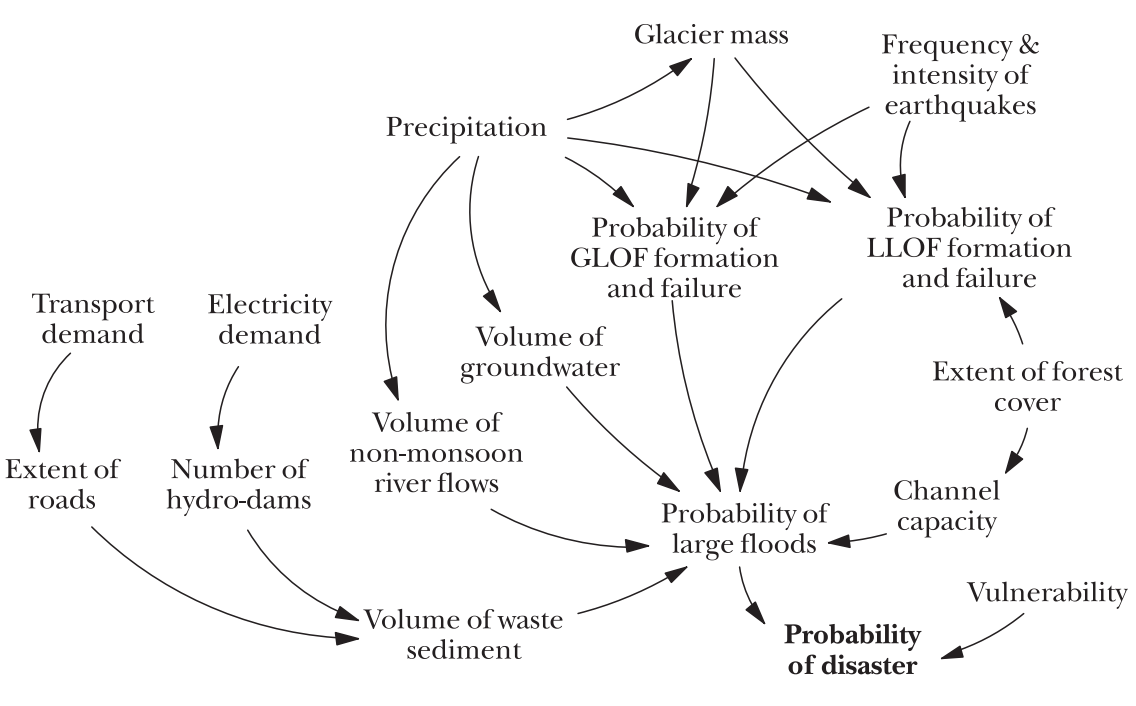

Source: Authors

contains glacier mass and volume of groundwater as key variables. When a glacier retreats it leaves behind piles of sediment that dams meltwater and precipitation run-off, producing lakes that can become enormous in size. These dams often burst, by groundwater sapping, overtopping and shaking by earthquakes to produce Glacial Lake Outburst Floods (GLOFs).

Such floods can be very destructive. ${ }^{24}$ In the Kali Gandaki valley of Nepal GLOF discharges are seven times higher than those of "normal" monsoon floods, while in the Mount Everest region the difference can be sixty-fold. ${ }^{25}$ GLOFs can easily produce flows of $30,000 \mathrm{~m}^{3} \mathrm{sec}^{-1}$ with velocities up to $14 \mathrm{msec}^{-1}$, drain lakes up to $50 \times 10^{6} \mathrm{~m}^{3}$ in volume, and reach from $200 \mathrm{~km}$ downstream ${ }^{26}$ to $1,200 \mathrm{~km}$ downstream. ${ }^{27}$ The frequency of such events appears to be increasing in the Himalaya as glaciers retreat and glacial lakes increase in area by up to 65 percent. ${ }^{28}$ Where glaciers are advancing in the

24 Cheryl Colopy, Dirty, Sacred Rivers. Confronting South Asia's Water Crisis (United Kingdom: Oxford University Press, 2012).

25 Summarized by Robert J. Wasson et al., "A 1000-year History of Large Floods in the Upper Ganga Catchment, Central Himalaya, India,” Quaternary Science Reviews 77 (2013): 156-166.

26 Shaun D. Richardson and John M. Reynolds, "An Overview of Glacial Hazards in the Himalayas," Quaternary International 65 (2000): 31-47.

27 Kenneth Hewitt, "Natural Dams and Outburst Floods of the Karakoram Himalaya," IAHS 138 (1982): 259-269.

28 Julie Gardelle, Yves Arnaud and Etienne Berthier, "Contrasted Evolution of Glacial Lakes along the Hindu Kush Himalaya Mountain Range between 1990 and 2009," Global and Planetary Change 75 , no. 1 (2011): 47-55. 
Hindu Kush-Karakoram the area of glacial lakes has decreased by about 50 percent between 1990 and 2009. The threat from GLOFs in this region is highly variable, spatially. ${ }^{29}$ In Tibet the threat of such floods is also likely to be high. ${ }^{30}$

When glaciers advance they can dam tributary valleys and produce glacial lakes. GLOFs from this source appear to be smaller than from lakes created by retreating glaciers. ${ }^{31}$

Landslides triggered by earthquakes or rainfall can dam valleys and produce huge lakes that burst, producing Landslide Lake Outburst Floods (LLOFs) (figure 3). Also, as glaciers retreat, their buttressing of valley walls decreases and landslides can result, forming dams and floods as destructive as GLOFs. The LLOF of 1786 in the Yangtze, with a peak discharge of about $37 \times 10^{3} \mathrm{~m}^{3} \mathrm{sec}^{-1}$ and a velocity of about $3.5 \mathrm{~m} \mathrm{sec}^{-1}$, claimed about 100,000 lives. $^{32}$

The 2008 Wenchuan earthquake in Sichuan, with a magnitude of 7.9, triggered a huge number of landslides and debris flows ${ }^{33}$ on the eastern margin of the Tibetan Plateau. ${ }^{34}$ The landslides and ground motion, which destroyed whole towns, killed 87,587 people $^{35}$ and displaced many more. Many landslides generated LLOFs, the largest of which was at Tangjiashan with a peak discharge of $15.4 \times 10^{3} \mathrm{~m}^{3} \mathrm{sec}^{-1}$. The volume of sediment delivered to the rivers was $0.19 \times 10^{9} \mathrm{~m}^{3}$ (about 5 percent of the total landslide volume), within a few years of the earthquake. ${ }^{36}$ The remainder awaits transport to the rivers, a process that Huang and Fan estimate will take several decades. However the rivers have already aggraded by more than 10 metres $^{37}$ and possibly 30 metres. ${ }^{38}$ The cities of Yingxiu and Qingping were destroyed by

29 Raphael Worni, Christian Huggel, and Markus Stoffel, "Glacial Lakes in the Indian HimalayasFrom an Area-wide Glacial Lake Inventory to On-site and Modeling based Risk Assessment of Critical Glacial Lakes,” Science of the Total Environment 468 (2012): S71-S84.

30 Weicai Wang et al., "A First-order Method to Identify Potentially Dangerous Glacial Lakes in a Region of the Southeastern Tibetan Plateau," Mountain Research and Development 31, no. 2 (2011): $122-130$.

31 John E. Costa and Robert Schuster, "The Formation and Failure of Natural Dams," Geological Society of America Bulletin 100, no. 7 (1988): 1054-1068.

32 F.C. Dai et al., "The 1786 Earthquake-triggered Landslide Dam and Subsequent Dam-break Flood on the Dadu River, Southwestern China," Geomorphology 65, no. 3 (2005): 205-221.

33 Runqiu Huang and Fan Xuanmei, "The Landslide Story," Nature Geoscience 6, no. 5 (2013): $325-326$.

34 Qiang Xu et al., "Landslide Dams Triggered by the Wenchuan Earthquake, Sichuan Province, South West China," Bulletin of Engineering Geology and the Environment 68, no. 3 (2009): 373-386.

35 USGS, "Earthquakes Hazard Program: Deaths from Earthquakes in 2008," last modified 21 April 2010, http://earthquake.usgs.gov/earthquakes/eqarchives/year/2008/2008_deaths.php, accessed 26 May 2014.

36 Xuanmei Fan et al., "Transient Water and Sediment Storage of the Decaying Landslide Dams Induced by the 2008 Wenchuan Earthquake, China," Geomorphology 171 (2012): 58-68.

37 Runqiu Huang and Xuanmei Fan, "The Landslide Story," Nature Geoscience 6, no. 6 (2013): 325-326.

38 D.L. Higgitt, University of Nottingham, Ningbo, China, personal communication, October 2013. 
the earthquake and were soon rebuilt, only to be flooded in 2010 by the Min River. The floods were caused by the bursting of dams created by large debris flows derived from landslides. ${ }^{39}$

The Wenchuan earthquake triggered archetypical compound disasters. In addition to ground motion, landslides, debris flows, LLOFs, and flooding, the earthquake also caused a toxic chemical spill from an industrial complex in Shifang in the Sichuan Basin. As a result most of China's production of wind turbines and hydroelectricity production in the mountains was disrupted..$^{40}$ These impacts on industry are not reflected in figure 3 because they require further analysis.

The impact of earthquakes as causes of landslides and glacial lake dam failure (figure 3) has probably been underestimated, when the impacts of giant earthquakes are considered. Mugnier et al. ${ }^{41}$ show that in the central Himalaya, earthquakes with magnitudes of 8.1 or greater can occur at any time. An earthquake larger or equal to 8.6 magnitude cannot be excluded.

Estimates of the time to failure of GLOFs and LLOFs are highly relevant to governance. About 56 percent of landslide dam lakes worldwide fail within a month of their formation, and about 85 percent fail within a year. ${ }^{42}$ Korup et al.$^{43}$ showed that both landslide and glacial dams fail after one to a hundred years in low relief catchments in the Himalaya, but in high relief landscapes they last between eight hours and one year. Hence, there is little time to artificially drain many of these lakes-even if it was technically possible and not prohibitively expensive. ${ }^{44}$

Forest cover also affects LLOFs because removal of vegetation can lead to landslides (figure 3 ).$^{45}$ This process, along with earthquakes, can increase sedimentation in river channels, reducing their capacity and exacerbating floods, ${ }^{46}$ as seen in Uttarakhand in June 2013 where valley floors were raised by up to 50 metres by landslide debris, increasing the vulnerability of

39 Q. Xu et al., "The 13 August 2010 Catastrophic Debris Flows after the 2008 Wenchuan Earthquake, China,” Natural Hazards and Earth System Science 12, no. 1 (2012): 201-216.

40 Y.-M Wei, J.-L. Jin, and Q. Wang, "Impacts of Natural Disasters and Disasters Risk Management in China: The Case of China's Experience in Wenchuan Earthquake," in Economic and Welfare Impacts of Disasters in East Asia and Policy Responses, eds. Y. Sawada and S. Oum (Jakarta: ERIA research report, 2012), 641-675.

41 J.-L. Mugnier et al., "Structural Interpretation of the Great Earthquakes of the Last Millennium in the Central Himalaya," Earth Science Reviews 127 (2013): 30-47.

42 John E. Costa and Robert L. Schuster, "The Formation and Failure of Natural Dams," Geological Society of America Bulletin 100, no. 7 (1988): 1054-1068.

43 Oliver Korup, David. R. Montgomery, and Kenneth Hewitt, "Glacier and Landslide Feedbacks to Topographic Relief in the Himalayan Syntaxes," Proceedings of the National Academy of Sciences 107, no. 12 (2010): 5317-5322.

44 Colopy, Dirty, Sacred.

45 See for example, Robert J. Wasson et al., "The Mountain-lowland Debate: Deforestation and Sediment Transport in the Upper Ganga Catchment," Journal of Environmental Management 88, no. 1 (2008): 53-61.

46 Robert J. Wasson, “Upland Deforestation, Erosion, and Downstream Impacts," in Deforestation Research Progress, eds. I.B. Sanchez and C.L. Alonso (New York: Nova Science Publishers, 2008). 
settlements to subsequent floods. Precipitation also adds to the groundwater store and therefore to flood magnitude through its influence on baseflow (low-flow during the dry season). Immerzeel et al. showed by modelling that the highest future baseflows in the Himalaya are likely to occur during May to September; thus they largely coincide with the monsoon season and are therefore liable to increase the subsequent flood threat. Meltwater from snow and glaciers can further raise the baseflow in rivers and the flood threat.

It is not only glaciers that are changing in India. Precipitation does not show a nation-wide trend, ${ }^{47}$ but there are areas where rainfall is either decreasing or increasing. Monsoon rainfall in the Himalayas is increasing only in Jammu and Kashmir, and elsewhere there is no statistically significant trend..$^{48}$ In Pakistan precipitation has increased..$^{49}$ An upward trend has however occurred during the last century in the frequency of "break monsoons" in India. ${ }^{50}$ During these events heavy rainfall occurs over the Himalaya.$^{51}$ This set of processes produces floods in the lower mountains.

A reconstruction of large-flood frequency in the Upper Ganga catchment for the last millennium shows that floods have become more common since 1750 , with a cluster in the eighteenth century. ${ }^{52}$ The cluster is possibly related to outbreaks of Arctic air meeting northward surges of the monsoon..$^{53}$ As a result of warming, if Arctic air more frequently reaches the mountains of Central and South Asia,${ }^{54}$ then large floods may become more frequent.

Another process may affect the magnitude of floods. If large amounts of sediment are available floods can be bulked up, producing a greater flow magnitude. This idea comes from an analysis of debris flows from volcanoes..$^{55}$ In addition to the large amounts of naturally derived sediment, substantial amounts of sediment have reached rivers in the Himalaya from the construction of roads and hydro-dams driven by the demand for transport and electricity (figure 3). Also giant earthquakes ${ }^{56}$ could deliver huge

47 P. Guhathakurta and M. Rajeevan, "Trends in the Rainfall Pattern over India," International Journal of Climatology 28, no. 11 (2008): 1453-1469.

48 Guhathakurta and Rajeevan, "Trends in the Rainfall," 1453-1469.

49 Massimo A. Bollisina, Yi Ming, and V. Ramaswamy, "Anthropogenic Aerosols and the Weakening of the South Asian Summer Monsoon,” Science 334, no. 6055 (2011): 502-505.

50 Ramesh Kumar et al., "Increasing Trend of 'Break Monsoon' Conditions over India-role of Ocean-atmosphere Processes in the Indian Ocean," IEEE Geoscience and Remote Sensing Letters 6, no. 2 (2009): 332-336.

51 K. Raghavan, "Break-Monsoon over India,” Monthly Weather Review 101, no. 1 (1973): 33-43.

52 Wasson et al., "A 1000-year History," 156-166.

53 For an analysis of the June 2013 flood disaster in the Indian state of Uttarakhand, see S. Joseph et al., "Extended Range Prediction of Uttarakhand Heavy Rainfall Event by an Ensemble Prediction System based on CFSv2" (Pune: IITM, ESSO, MoES, 2013), http://www.tropmet.res.in/ lip/ Publication/RR-pdf/RR-131.pdf, accessed 10 May 2015.

54 Jennifer A. Francis and Stephen J. Vavrus, "Evidence Linking Arctic Amplification to Extreme Weather in Mid-latitudes," Geophysical Research Letters 39, no. 6 (2012): 6.

55 E.E. Doyle, S.J. Cronin, and J.-C. Thouret, "Defining Conditions for Bulking and Debulking in Lahars," Geological Society of America Bulletin 123, no. 7-8 (2011): 1234-1246.

56 Mugnier et al., "Structural Interpretation," 30-47. 
amounts of sediment to rivers, causing flow bulking (figure 3). The 2013 Uttarakhand flood, which damaged many hydro-dams along with villages, roads, and bridges, in addition to killing many (about 30,000) people (mostly Hindu pilgrims), ${ }^{57}$ has had a negative feedback on future plans for further hydro-dams, a link not shown on figure 3 because the results of the current debate are not yet known.

The vulnerability of communities in the Himalayas to floods has received little analysis, a situation that may change following the June 2013 catastrophic flood in the Upper Ganga catchment. ${ }^{58}$ However, building in dangerous locations, along river banks and within the limits of great floods, flimsy construction, absence of clear evacuation plans and early warning systems, and crowding during peak tourism times have all contributed to increased vulnerability. The physical system is much better understood than the social system. If improvements in understanding of likely physical futures are to be of value they must be accompanied by a better understanding of human vulnerability.

\section{Floods on the Plains}

The water-related threats on the plains adjacent to the mountains and plateau are depicted in figure 4; where floods are mostly a direct consequence of precipitation as shown in figure 3. However, GLOFs and LLOFs are not included in the figure because they rarely reach the plain except for the 1970 Alaknanda River and the 1968 Tista River floods, ${ }^{59}$ the above-mentioned Sichuan floods, and a LLOF in 1841 that travelled over $300 \mathrm{~km}$ in the Indus River and killed thousands of Sikh troops at Attock. ${ }^{60}$

Three-quarters of the largest floods in India occur during excess monsoon periods. ${ }^{61}$ In the Ganga River excess monsoon periods with accompanying floods occurred in the periods 1880-1900, 1910-1923, 1930-1960, 1970-1977, and 1990-2005, with the largest floods since 1960 in the Ganga, the Yamuna, and the Indus. Intensity of rainfall is also important,${ }^{62}$ particularly after 1970 , with more intense but less frequent tropical cyclones forming in the Bay of Bengal and possibly some enhancement of run-off by land-cover change.

57 Alan D. Ziegler et al., "Pilgrims, Progress, and the Political Economy of Disaster PreparednessThe Example of the 2013 Uttarakhand Flood and Kedarnath Disaster," Hydrological Processes 28, no. 24 (2014), DOI:10.1002/hyp.10349.

58 NIDM (National Institute of Disaster Management), "Uttarakhand Disaster 2013: Lessons Learnt," Preliminary Report, (2013): 196, http://nidm.gov.in/pdf/pubs/proc\%20ukw-13.pdf.

59 Wasson et al., "The Mountain-lowland," 53-61; Wasson, "Upland Deforestation."

60 Robert W.-H. Butler, Lewis Owen, and David J. Prior, "Flashfloods, Earthquakes and Uplift in the Pakistan Himalayas,” Geology Today 4, no. 6 (1988): 197-201.

61 Vishwas Kale, "On the Link between Extreme Floods and Excess Monsoon Epochs in South Asia," Climate Dynamics 39, no. 5 (2012): 1107-1122.

62 Kale, "On the Link," 1107-1122. 
Figure 4

Floods on the Plains

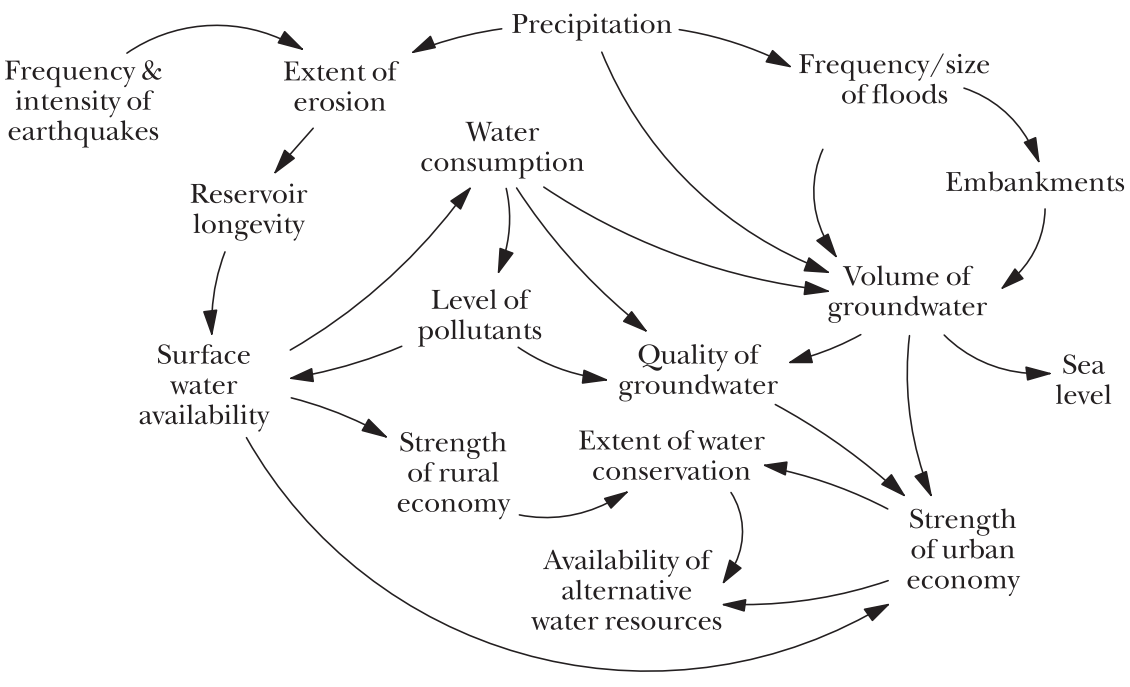

Source: Authors

Mirza $^{63}$ finds that extreme floods in South Asia appear to be increasing with expansion of flood-prone areas, and are causing serious economic impacts. For instance, in Bangladesh a reduction of GDP of 0.3 percent resulted from the floods in 2007 and $2008 .^{64}$

Floodwaters that spread beyond their channels are likely to be important for groundwater recharge (figure 4). Most river water and groundwater on the Gangetic Plain is derived from rainfall, ${ }^{65}$ a conclusion consistent with the estimate that the Ganga contains 3 percent to 9 percent meltwater. The Indus contains more meltwater, ${ }^{66}$ consistent with an estimate of up to 56 percent quoted above.

Floods on the Ganga and its tributaries are damaging, especially in the east and in the state of Bihar in particular. A linear-regression analysis shows that there is no statistically significant trend in the area affected by

63 Monirul M. Q. Mirza, "Climate Change, Flooding in South Asia and Implications," Regional Environmental Change 11, no. 1 (2011): S95-S107.

64 Mirza, "Climage Change," S95-S107.

65 S.K. Gupta and R.D. Deshpande, "Groundwater Isotopic Investigations in India: What has been Learned?" Current Science 89, no. 5 (2005): 825-835; Luc Lambs et al., "Oxygen and Hydrogen Isotopic Composition of Major Indian Rivers: A First Global Comparison,” Hydrological Processes 19, no. 17 (2005): 3345-3355.

66 Lambs et al., "Oxygen and Hydrogen," 3345-3355. 
floods in Bihar between 1953 and 2011 ${ }^{67}$ However the total damage to crops, houses, and public utilities shows a statistically significant upward linear trend. The maximum damage was in 2005 with a total of US\$64 million. Even in cases where the threat level remains constant, damage has been increasing, presumably because of increased floodplain population and infrastructure.

Floods carry large amounts of sediment that reduces the water-storage capacity of reservoirs, which are mostly in the foothills of the Himalaya. But the effect of storage loss is felt most acutely on the plain, where the water is used for irrigation and the hydro-electricity is also mainly used (figure 4). It is estimated that Indian reservoirs annually lose on average 0.5 percent of their storage by sedimentation, with higher rates in some parts of the Himalaya ${ }^{68}$ In Pakistan the loss was 0.9 percent per annum in the Tarbela Reservoir between 1974 and 2000, and 0.5 percent per annum in the Mangla Reservoir between 1967 and 2007. ${ }^{69}$ Within a few decades, between 20 and 29 percent of storage has been lost in a country where demand for irrigation water is rising. Tarbela Reservoir alone provides 49 percent of Pakistan's installed hydroelectric capacity, and much of the water is used for irrigation, which in turn produces 90 percent of the food in the country. ${ }^{70}$ Erosion and sediment transport into reservoirs are processes amplified by earthquakes and land use in critical zones (figure 4$){ }^{71}$

Declining surface-water availability is accelerating the search for alternative water sources. This has led to a rediscovery of traditional methods such as water harvesting (figure 4) ${ }^{72}$ Interest in water conservation and alternative sources appears to be driven by an awareness of increasing vulnerability, as populations and water demand increase in cities such as Delhi, where reticulation is incomplete or ineffective, and pumping is dependent on an unreliable electricity supply. ${ }^{73}$

Pollution poses another threat to surface water availability (figure 4$).^{74}$ Industrial and domestic wastes have made the surface waters of much of the plains of India and Pakistan unusable for potable and even industrial purposes

67 Government of India, "State Wide Flood Damage Statistics," Central Water Commission, Delhi, 2012, http://www.cwc.gov.in/main/downloads/FFM.2200-2291.27112012.pdf, accessed 27 May 2014.

68 G.L. Morris, "Reservoir Sedimentation and Sustainable Development in India," Proceedings of the Sixth International Symposium on River Sedimentation (New Delhi, India, 1995), 57-61.

69 David R. Archer et al., "Sustainability of Water Resources Management in the Indus Basin under Changing Climatic and Socio Economic Conditions," Hydrology and Earth System Science 14 (2010): 1669-1680.

70 Cook et al., "Five Centuries," 365-375.

71 Wasson et al., "The Mountain-lowland," 53-61.

72 Colopy, Dirty, Sacred Rivers.

73 Colopy, Dirty, Sacred Rivers.

74 Colopy, Dirty, Sacred Rivers; Robert J. Wasson, "Water Quality and Economic Growth in India," in Water First: Issues and Challenges for Nations and Communities in South Asia, eds. Lahiri-Dutt Kuntala and Robert. J. Wasson (New Delhi: Sage, 2008), 99-110. 
without expensive treatment. Downstream of cities, water quality also compromises irrigation uses, forcing the use of groundwater. It is estimated that 70 percent of irrigation needs are met by groundwater, with 30 percent met by surface water. ${ }^{75}$ The vulnerability of people to surface-water pollution has been greatly increased by a lack of regulation and treatment of wastes.

Depletion and pollution of groundwater are serious problems. More than 80 percent of rural water supplies come from this source ${ }^{76}$ In Pakistan about 90 percent of agricultural production comes from irrigated lands, and this contributes to 24 percent of GDP, 70 percent of export income, and provides employment for about 50 percent of the civilian workforce. ${ }^{77}$ About 90 percent of extracted groundwater is used for agriculture, the remainder being used for domestic and industrial purposes. Overuse of groundwater has, for example, made this source of water inaccessible in 5 percent of Punjab Province-a figure likely to increase to 20 percent by 2019 or so. ${ }^{78}$

Groundwater loss has been estimated from satellite-based measurements of Earth's gravity field. Tiwari et al. ${ }^{79}$ show that the loss from the GangaBrahmaputra catchments is about 34 cubic kilometres (13,600 Olympic swimming pools) per year, and about 10 cubic kilometres (4000 Olympic swimming pools) per year from the Indus catchment. Groundwater is being extracted in India at a rate much higher than the recharge rate. Incredibly the loss of groundwater from this region is sufficient to have raised sea level by about $0.16 \mathrm{~mm} \mathrm{yr}^{-1}$ between 2002 and 2006, a threat to coastal communities (figure 4). This occurs because most of the extracted groundwater is lost by evapotranspiration and run-off to the ocean. Between 2000 and 2008 global extraction of groundwater has contributed about 13 percent to total sea level rise. ${ }^{80}$

Water consumption is an influence on both groundwater quantity and quality (figure 4). As groundwater beneath the Gangetic Plains is depleted it has become contaminated by arsenic, salts, and fluoride, along with heavy metals from industry, nitrate from chemical fertilizer, and pesticide residues from agriculture. Pollution is particularly serious in urban areas where groundwater is the most important source of drinking water. ${ }^{81}$ Deteriorating

75 Vasant P. Gandhi and N.V. Namboodiri, "Groundwater Irrigation in India: Gains, Costs and Risk" (Ahmedabad: Indian Institute of Management, 2009), 38.

76 P.K. Nail, "Peak Water and Demand Side Management," Current Science 105, no. 7 (2013): $884-885$.

77 Asad S. Qureshi and M.T. Akhtar, "The Groundwater Economy of Pakistan" (Lahore: International Water Management Institute, 2003), 23.

78 Asad S. Qureshi et al., "Challenges and Prospects of Sustainable Groundwater Management in the Indus Basin, Pakistan,” Water Resource Management 24, no. 8 (2009): 1551-1569.

79 V.M. Tiwari, J. Wahr, and S. Swenson, "Dwindling Groundwater Resources in Northern India, from Satellite Gravity Observations,” Geophysical Research Letters 36, no. 18 (2009).

80 Leonard F. Konikow, "Contribution of Global Groundwater Depletion since 1900 to Sea-level Rise," Geophysical Research Letters 38, no. 17 (2011).

81 Dinesh M. Kumar and Tushaar Shah, "Groundwater Pollution and Contamination in India: The Emerging Challenge," International Institute of Water Management 1, no. H043613 (2006): 6. 
groundwater quality impacts on human health and availability of potable water, and therefore influences both rural and urban economies through costs of water treatment, particularly in cities. ${ }^{82}$ These economic impacts are reflected in increased conservation, use of alternative sources of water (figure 4), drip irrigation, pricing of water, regulation of extraction, underground pipes to replace open canals, and by growing more water-efficient crops ${ }^{83}$

The main conclusion to be drawn from this section is that, to our knowledge, the linkages shown in figure 4 are not the focus of research. Research targeted at testing and quantifying the links is likely to reap large rewards.

\section{Levees}

Governments have reacted to damaging floods in India, Bangladesh, China, Thailand, and elsewhere by building levees (embankments) along rivers. Much has been written about the effectiveness of levees. ${ }^{84}$ We focus on an unexpected consequence of levee construction: the tendency of levees to increase flood losses, illustrated with the causal-loop diagram (a type of cause-effect diagram) of figure $5{ }^{85}$ In the causal-loop diagram of figure 5 the text describes state variables, and the arrows depict state-change processes. The positive and negative signs indicate link "polarity." A positive sign means that an increase (decrease) in the value of the influencing variable will cause the value of the affected variable to rise above (fall below) the value that it would otherwise have had, all else being equal. A negative sign means that an increase (decrease) in the value of the affecting variable will cause the value of the affected variable to decrease below (increase above) the value that it would otherwise have had, all else being equal. ${ }^{86}$ This analysis posits a plausible set of connections that needs to be tested in different physical and social settings.

The diagram shows four positive (reinforcing) feedback loops. The "severity" loop (R1) shows how flood losses lead to public pressure for action, including levee construction-with benefits to politicians, bureaucrats, and

82 Kumar and Shah, "Groundwater Pollution," 6.

83 Tushaar Shah, "Climatic Change and Groundwater: India's Opportunities for Mitigation and Adaptation,” Environmental Research Letters 4 (July-September 2009) 035005 doi:10.1088/1748 $-9326 / 4 / 3 / 035005$

84 See Dinesh K. Misra, River Bagmati: Bounties become a Curse (India: SANDRP and Peoples' Science Institute, 2012), 196; James K. Boyce, "Birth of a Megaproject: Political Economy of Flood Control in Bangladesh,” Environmental Management 14, no. 4 (1990): 419-428.

85 This diagram is adapted from Barry Newell and Robert J. Wasson, "Social System vs. Solar System: Why Policy Makers Need History," in Conflict and Cooperation Related to International Water Resources: Historical Perspectives, eds. S. Castelein and A. Otte (Grenoble: UNESCO, 2002), 3-17, http:// unesdoc.unesco.org/images/0012/001280/128073e.pdf, accessed 27 May 2014.

86 Newell and Wasson, "Social System vs. Solar System." 
Figure 5

The Flood Embankment Imbroglio

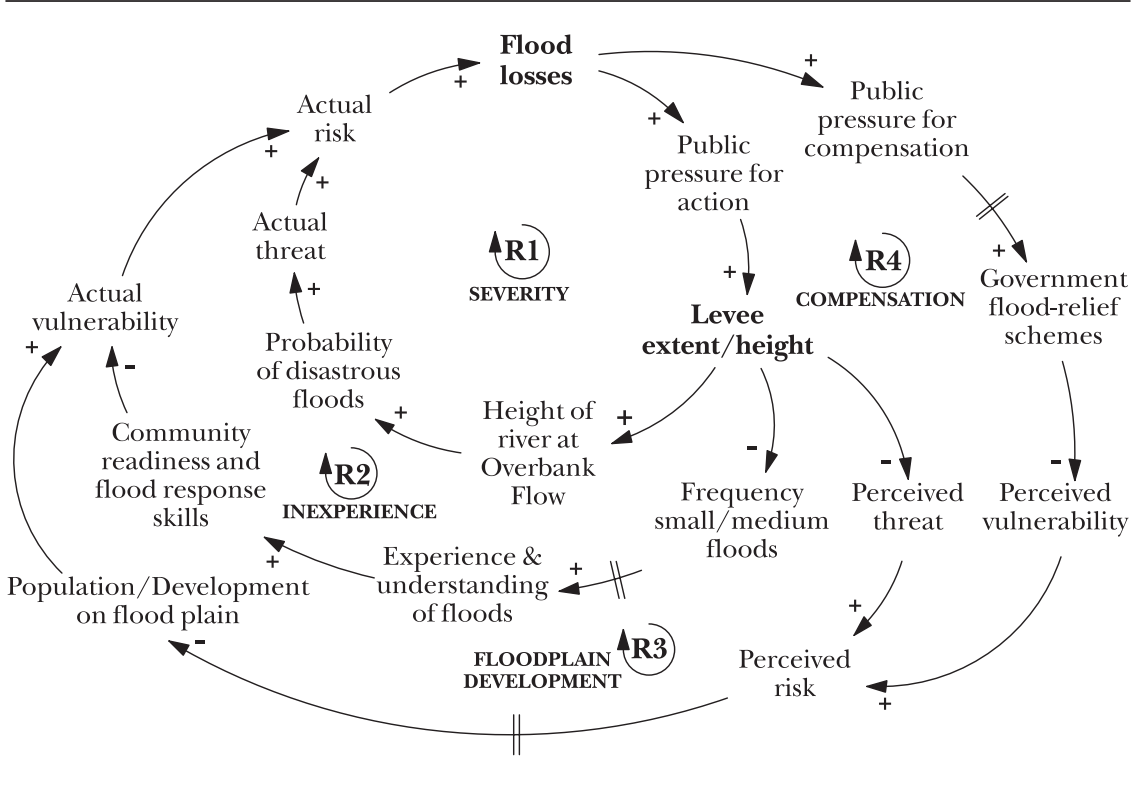

Source: Authors

construction companies. ${ }^{87}$ But levees cause sedimentation that decreases flow capacity. ${ }^{88}$ The resulting increased probability of disastrous floods increases the actual threat and thereby the magnitude of flood losses.

The "inexperience" loop (R2) shows how levees can reduce the frequency of small to medium floods, thereby reducing opportunities for the community to learn about and react to floods, increasing their actual vulnerability, the actual risk, and the losses. The "floodplain development" (R3) loop shows how levees reduce the community's perception of the hazard and risk. This perception leads to increased population and infrastructure development on floodplains, increasing the community's actual vulnerability, actual risk, and eventual losses. The "compensation" loop (R4) shows that flood losses give rise to public pressure for compensation. This pressure leads to flood-relief schemes, reducing both the community's perception of the vulnerability of floodplain dwellers and the perceived risk, increasing floodplain development and population. Thus, loop R4 strengthens the impact of loop R3.

87 In the case of Bangladesh, see Imtiaz Ahmed, "Governance and Flood: Critical Reflections on the 1998 Deluge," Futures 33, no. 8 (2001): 803-815.

88 R. Sinha et al., "Exploring the Channel Connectivity Structure of the August 2008 Avulsion Belt of the Kosi River, India: Application to Flood Risk Assessment," Geology 41, no. 10 (2013): 1099-1102. 
The same argument for increased vulnerability can be made for those living downstream of dams that are claimed to control floods. ${ }^{89}$ In addition, the limiting of most floodwaters to relatively narrow areas by levees along rivers may reduce groundwater recharge (figure 4).

\section{Synthesis, Key Governance Issues, and Concluding Remarks}

The four cause-effect diagrams present our basic dynamic hypotheses. Figure 2 reflects the physics of the ways that climate affects glaciers and nonmonsoon flows. If these flows are increased by meltwater they can increase flood flows in subsequent monsoons. This effect is included in figure 3, which introduces other factors affecting flood levels in the mountains. These factors include groundwater, GLOFs and LLOFs, river channel capacity and waste sediment, and their main controls, both physical and human. The analysis is extended to the plains adjacent to the mountains in figure 4 , where floods are largely the result of precipitation on the plains rather than in the mountains. This figure also introduces other water phenomena that, when linked to floods, can produce compound disasters. The sedimentation of reservoirs, mainly in the mountains (with effects mainly on the highly populated plains) and augmented by floods in erosion-prone terrain, worsens when floods become larger. As reservoir water availability lessens, and as surface water becomes polluted, groundwater becomes a source of greater value. But it too can be compromised by pollution, leading to a search for alternative water supplies and severe effects on both urban and rural economies. Embankments, the favoured response to large floods on the plains, may reduce groundwater recharge, a water resource that is already being overdrawn with a far-field impact on sea level. Devoting figure 5 to the complex effects of this common flood-mitigation strategy emphasizes the impact of embankments on the plains. In this causal loop diagram, human perception, political pressure, flood relief schemes, response skills, and floodplain development are included to show that embankments may increase risk rather than diminish it.

Our cause-effect diagrams, and the accompanying narrative, do not include an analysis of the delays between cause and effect, a potentially key limit on the credibility of policy interventions. This issue must await further research. An immediate need is for a deeper understanding of the key system variables, their interconnections, and their behaviour over time. This understanding is necessary before any useful modeling of the system is possible.

In an increasingly connected world, with a growing population and increasing urbanization, the linkages between threats and vulnerability are

89 Fred Pearce, The Dammed: Rivers, Dams and the Coming World Water Crisis (London: the Bodley Head, 1992), 376. 
deepening, a connectivity illustrated by a systems approach. Governance, in a system-dynamics worldview, should begin by understanding the parts (variables) and the interconnections (influences, feedbacks, and delays), be capable of asking questions about the future, and lead to creative redesign of systems.${ }^{90}$ But this is a huge challenge for current governance regimes that typically deal with small parts. Yet it should be clear from this paper that "atomized governance" cannot deal effectively with interconnected problems. Current disconnected governance approaches have a significant chance of leading to a collapse of the water management system. ${ }^{91}$

How can governance cope with a large and complex system of the kind sketched in these pages? Adaptive governance ${ }^{92}$ is one possible way, involving collaboration, social learning, flexibility, and polycentrism; that is, an emphasis on vulnerability reduction through the agency of polycentrism or "bottom-up" approaches. ${ }^{93}$ This approach would be a radical departure from top-down government programs that, once instituted, are rarely changed, assumed to work everywhere ${ }^{94}$ and have little local design input and organization..$^{95}$ Sharing of rights and responsibilities between actors, partnerships to support collective action, a capacity to learn and respond to changed circumstances and knowledge, and multiple nodes of decision making are essential elements of a water governance system that acknowledges the links between floods and other water-related phenomena.

A need for innovative governance and adaptation are recommended for climate change as well, ${ }^{96}$ an approach that can inform the problems presented here. In contrast, the linear thinking embedded in the IPCC analysis of adaptation-where a climatic threat is assessed to have a particular impact, given certain vulnerability, leading to an adaptive response that is only an adjustment-has been criticized for ignoring the political economic critique of the 1970s and 1980s of the relation between hazards, risk, and vulnerability. ${ }^{97}$ If the IPCC approach is used as part of a governance framework for the connections presented here, it will fail to properly take into account the functional relationship between risk and vulnerability with threats as

90 Meadows, Thinking in Systems.

91 Thomas Homer-Dixon, Complexity Science and Public Policy: New Directions Series (Toronto: Institute of Public Administration of Canada, 2010), 19.

92 Carina Wyborn and Stephen Dovers, "Prescribing Adaptiveness in Agencies of the State," Global Environmental Change: Part A - Human and Policy Dimensions 14 (2013): 5-7.

93 Thomas J. Bassett and Charles Fogelman, "Déjà vu or Something New? The Adaptation Concept in the Climate Change Literature," Geoforum 48 (2013): 42-53; Daniel H. Cole, "Advantages of a Polycentric Approach to Climate Change Policy," Nature Climate Change 5, no. 2 (2015): 114-118.

94 Claudia Pahl-Wostl et al., "From Applying Panaceas to Mastering Complexity: Toward Adaptive Water Governance in River Basins,” Environmental Science and Policy 23 (2012): 24-34.

95 Vaibhav Kaul and Thomas Thornton, "Resilience and Adaptation to Extremes in a Changing Himalayan Environment,” Regional Environmental Change 14, no. 2 (2014): 683-698.

96 Daivi Rodima-Taylor, Mette F. Olwig, and Netra Chhetri, "Adaptation as Innovation, Innovation as Adaptation: An Institutional Approach to Climate Change," Applied Geography 33 (2012): 107-111.

97 Bassett and Fogelman, "Déjà vu or Something New," 42-53. 
triggers for disasters. Furthermore, it will not lead to transformative adaptation to reduce vulnerability. Any adaptive strategy for interconnected water issues will require flexibility and staged interventions probably based on scenarios rather than fully functioning system models, along the lines described by Felgenhaur and Webster. ${ }^{98}$

An adaptive future presents another challenge for governance of large and highly interconnected systems. The increasing call for more participatory involvement of local communities in disaster governance, to balance the hegemony of experts and enable local organization, may also need to be re-examined. While we do not challenge the call for more participatory involvement, as it is crucial to a polycentric regime, local solutions are unlikely to have an impact on the system at large if a more integrated framework is not adopted. The role of experts then becomes one of helping the community, NGOs, and governments to see the cross-sector interactions, and to assist in designing local solutions that contribute not only locally, but also regionally and globally. The extent to which knowledge of such a large system can be co-produced by experts and civil society, in the way suggested by Lane et al. ${ }^{99}$ admittedly at a much smaller scale, has not been tested.

Another governance issue is the propagation of false hope. We have shown how levees can increase flood risk, rather than reduce it. Dams are often touted as a solution to flooding, a view put in an unqualified fashion by the International Commission on Irrigation and Drainage, but challenged by many, including Pearce and Sadoff et al. ${ }^{100}$ Dams and levees involve policy lock-in so that, once implemented, their efficacy is not reviewed and adverse effects are ignored: the opposite of adaptive governance. Equally worrying is governance deficit in countries where there is no process that would enable adaptive governance. ${ }^{101}$

The last issue is perhaps the least tractable: cross-border governance. Between 31 and 97 percent of the renewable water in the catchments in figure 1 crosses international borders. ${ }^{102}$ The headwaters of almost all of the major rivers in the region lie in China on the Tibetan Plateau, where dam building is causing considerable disquiet downstream, ${ }^{103}$ not only because

98 Tyler Felgenhaur and Mort Webster, "Multiple Adaptation Types with Mitigation: A Framework for Policy Analysis,” Global Environmental Change 23, no.6 (2013): 1556-1565.

99 Stuart N. Lane et al., "Doing Flood Risk Science Differently: An Experiment in Radical Scientific Method," Transactions of the Institute of British Geographers 36, no. 1 (2011): 15-36.

100 ICID (International Commission on Irrigation and Drainage), "Role of Dams for Irrigation, Drainage and Flood Control" (New Delhi, 2000), 21, http://www.icid.org/dam_pdf.pdf, accessed 27 May 2014; Pearce, "The Dammed"; Claudia Sadoff et al., "Ten Fundamental Questions for Water Resources Development in the Ganges: Myths and Realities," Water Policy 15 (2013): 147-164.

101 Richard Friend et al., "Mainstreaming Urban Climate Resilience into Policy and Planning: Reflections from Asia," Urban Climate 7 (2013): 6-19.

102 FAO (Food and Agriculture Organization), "Aquastat," 2013, http:/ /www.fao.org/nr/water/ aquastat/data/query/index.html?lang=en, accessed 3 May 2014.

103 Brahma Chellaney, Water: Asia's New Battleground (Washington, DC: Georgetown University Press, 2011), 386. 
of the possible loss of water and hydroelectric potential, but also because of impacts on fisheries, soil fertility, erosion of deltas and floods. Dams on the Tsangpo-Brahmaputra River may divert a large amount of water to the Yangtze River in China, reducing flows into India and Bangladesh. These dams are also claimed to be able to control floods, but there are suspicions that flash floods downstream of Chinese dams are a consequence of releases of water during heavy rainfall.

In the Indian state of Arunachal Pradesh in mid-2000 a flash flood, claimed by China to be a consequence of a natural dam breach, raised the Brahmaputra by $30 \mathrm{~m}$. But in 2000, according to analysis of satellite images by Indian authorities ${ }^{104}$ flash floods in Himachal Pradesh and Arunachal Pradesh were caused by water released from Chinese dams. The same is said to have occurred in Himachal in 2001 and 2005. ${ }^{105}$ The Chinese deny these claims. A flood in the Mekong in August 2008 affected Thailand and Laos severely and was also blamed on a sudden release of water from Chinese dams in Yunnan. But the Mekong River Commission concluded that the flood was a result of heavy rainfall and incomplete river levees. ${ }^{106}$ Whatever the truth, a lack of transparency has raised suspicions about the origin of flash floods. To this we can add the prospect of a major earthquake in the vicinity of one of China's mega-dams, ${ }^{107}$ leading to a breach and a major flood.

Figure 3 includes the influence of forests on floods through changes to the water balance (an unimportant effect for large floods), erosion, and channel capacity. The debate about these relationships has been raging for more than a century, providing one of the most obdurate examples of intellectual and civil-society lock-in. ${ }^{108}$ Chellaney cites modeling results that show that mean annual run-off is likely to have increased as a consequence of a major reduction in forest cover on the Tibetan Plateau and makes a highly qualified, and unconvincing, claim that floods may have also increased. The governance significance of this equivocal research is that it has become the basis for major public policies. Catastrophic floods in China were partly ascribed to deforestation, and the logging ban in 1998 put the livelihoods of minority people at risk. ${ }^{109}$ A similar ban was instituted in Uttar Pradesh in 1981 for similar reasons, spurred in particular by the Chipko Movement that

104 Shishir Gupta, "Made in China: Floods Ravage Himachal and Arunachal Pradesh, Satellite Pictures Suggest China's Hand,” Indiatoday, 25 June 2001, http:/ /indiatoday.intoday.in/story/floods -ravage-himachal-and-arunachal-pradesh-satellite-pictures-suggest-china-hand/1/232112.html, accessed 4 May 2014.

105 Chellaney, Water: Asia's, 386.

106 Mekong River Commission, "Lower Mekong Basin Flood Update," 25 August 2008, http:// www.prlog.org/10109246-lower-mekong-basin-flood-update.html, accessed 4 May 2014.

107 Yingzi Tan, "Yellow River Dams on Verge of Collapse," China Daily, 19 June 2009, www.chinadaily. com.cn/china/2009-06/19/content_8301942.htm, accessed 4 May 2014.

108 Wasson, "Upland Deforestation."

109 Jack Ives, Himalayan Perceptions: Environmental Change and the Well-being of Mountain Peoples (London: Routledge, 2004), 265. 
was in part a response to the 1970 Alaknanda flood. ${ }^{110}$ While these policies were aimed at national outcomes, floods on the Gangetic Plain were often blamed by Indian politicians on deforestation in Nepal and by Bangladeshi politicians on deforestation in India.

Solutions to floods that cross international boundaries require transboundary river catchment governance, but it is difficult to achieve anything meaningful in the current geopolitical environment. ${ }^{111}$ The increasing assertiveness of China, and promises by the newly elected government of India regarding a firmer policy toward China, suggest that the situation will not improve. In such circumstances, the sharing of information and knowledge, the establishment of joint warning systems, and dialogue between experts and people of influence would be helpful steps. ${ }^{112}$ Most of these views are shared by Sorg et al., ${ }^{113}$ who while discussing the Syr Darya catchment (figure 1), consider that it is also necessary for governments to take national responsibility and initiative. Chellaney goes further to argue that without institutions that can reduce competition and tension, including strategic doctrines and military expenditure, there will be little progress. He also adds that there is an imperative to build what he calls "Asian norms over shared transnational basin resources," 114 based on international customary water law, with a need for "truly inclusive river basin organizations and other cooperative mechanisms," 115 with appropriate agreements (some of which already exist). Agreements should include transparency, information sharing, equitable distribution of benefits, dispute settlement provisions, pollution control, plans for joint projects, and a commitment to maintain transboundary flows. The possibility of building institutions capable of reaching such agreements between all of the affected countries depends partly on the availability of a coherent conceptual framework using ideas such as those in this paper.

Dealing with the individual issues of water management and floods in cities and/or their hinterlands is a huge challenge, and efforts to date have not been highly successful. So why suggest an even more challenging objective, namely the management of the whole, using an adaptive approach to governance? Unless a more systemic approach is taken it is likely that the individual crises will coalesce to create mega-crises, as they are beginning to

110 Piers Blaikie and Joshua S.S. Muldavan, "Upstream, Downstream, China, India: The Politics of Environment in the Himalayan Region," Annals of the Association of American Geographers 94, no. 3 (2004): 520-548.

111 David J. Molden et al., "Water Infrastructure for the Hindu Kush Himalayas," International Journal of Water Resources Development 30, no. 1 (2014): 60-77.

112 Molden et al., "Water Infrastructure," 60-77.

113 A. Sorg et al., "Coping with Changing Water Resources: The Case of the Syr Darya River Basin in Central Asia,” Environmental Science and Policy 43 (2014): 68-77.

114 Chellaney, Water: Asia's, 386.

115 Chellaney, Water: Asia's, 386. 
do. However, such major crises do create windows of opportunity, ${ }^{116}$ but the international community's ability to take advantage of them clearly needs a vigorous preparation phase involving, we suggest, a large-scale inclusive analytical framework.

National University of Singapore, Singapore

The Australian National University, Canberra, Australia, March 2015

116 As described by Per Olsson et al., "Shooting the Rapids: Navigating Transitions to Adaptive Governance of Social-ecological Systems," Ecology and Society 11, no. 1 (2006): 18. 